\title{
Identification of Adaptive Capacity's Drivers in an Urban River Neighbourhood based on Community Experiences
}

\author{
Rohana Mohd Firdaus*, Mohd Hisyam Rasidi and Ismail Said \\ Department of Landscape Architecture, Faculty of Built Environment and Surveying, \\ Universiti Teknologi Malaysia, 81310 Skudai, Johor, Malaysia
}

\begin{abstract}
Urban river neighbourhood communities have been swiftly adapting to rapid urbanisation despite the unsolved issues with their rivers. These issues indicate that there are gaps that need to be addressed, particularly the ones related to social aspects. In an attempt to fill in those gaps, this study aimed to identify the drivers of the adaptive capacity of an urban river neighbourhood community in Kg. Pertanian, Kulai, Johor. Data were elicited through focus group discussions with 27 residents followed by subsequent personal interviews. The obtained transcriptions were analysed by Nvivo12. From the results, it was found that there were three dominant drivers, namely 'community identity', 'community response', and 'stakeholder agency'. 'Community identity' refers to the community's contentment with life and its essential neighbourly relationships. 'Community response' reflects the community's process of learning from experience and how its residents used the knowledge to benefit the community's well-being. Finally, 'stakeholder agency' encompasses the community's engagement and communication with stakeholders to avoid conflict during upcoming planning for its urban river and neighbourhood. These drivers were based on the community' experiences or social memory. Interactions during floods and community events became the foundation for social memory. The interactions also bonded the people in the community, which was evident from the residents' participation. All in all, the

ARTICLE INFO

Article history:

Received: 09 November 2020

Accepted: 15 March 2021

Published: 30 June 2021

adaptive capacity and consequently the resilience of the urban river neighbourhood community can be attributed to three drivers: 'community identity', 'community response', and 'stakeholder agency'.
\end{abstract}

DOI: https://doi.org/10.47836/pjssh.29.2.20

E-mail addresses:

rohana.edengroup@gmail.com (Rohana Mohd Firdaus)

b-hisham@utm.my (Mohd Hisyam Rasidi)

ismailbinsaid@gmail.com (Ismail Said)

* Corresponding author
Keywords: Adaptive capacity, community, neighbourhood, social memory, urban river 


\section{INTRODUCTION}

Communities are, undeniably, one of the keys to the world's sustainability, and are one of the backbones that make up nature (Darby \& Sear, 2008). Unfortunately, they have negatively affected the surrounding environments through their activities (Harper, 2004; Li et al., 2019). Examples of such activities include land expansion, especially in urban areas, for housing and industry have encroached upon rivers and placed pressure on river landscapes (Chan, 2005). Furthermore, these activities have caused urban rivers, which are known for their versatile functions for society (Baschak \& Brown, 1994; Chan, 2005) and are one of the focal points of this study, to deteriorate, as what happened in many countries, including Malaysia. The damage is further exacerbated by climate change that increases flood risk (Palmer et al., 2009; Verbrugge \& van den Born, 2018). Additionally, the rivers are also degraded by engineering works that changed their natural physical form (Gregory, 2006). All of these showed that human intervention would only damage urban rivers' functions and cause riverside communities to face the consequences.

It has been shown in history that humans established their neighbourhoods close to rivers for many reasons, which included disposing of waste. Then, the established neighbourhoods became a place for social interaction (Baschak \& Brown, 1994; Chan, 2005; Rahman \& Yatim, 1990). Over time, emotional bonds between communities in the neighbourhoods developed (Gleye, 2015), even when the neighbourhoods were urbanised. Disappointingly, they have also become the polluters of rivers. Pollution is not a new issue in urban river studies as it has surfaced since the early industrial era (Chan, 2009; Chan et al., 2003; Chen et al., 2018; Elfithri et al., 2011; Eze \& Knight, 2018; Kumar et al., 2018; Wang, 2018). Serious attention is needed to address urban river degradation from a social perspective. This situation is worsened by the lack of concern from the communities, despite the efforts to raise awareness (Sakai et al., 2018). The negative impact of this mostly goes back to the communities that live close to urban rivers (Chiang, 2018). This situation reveals how urban rivers that were once strategic locations for neighbourhoods deteriorate due to developments (Asakawa et al., 2004). It also shows how the communities in the neighbourhoods are instrumental in curbing this problem.

Particularly in Malaysia, rivers are one of life's sources that were historically responsible for the growth of neighbourhoods (Chan et al., 2003). Md. Yassin et al. (2010) believed that without rivers, Malaysia would not have its glory in history. As this study focused specifically on identifying the adaptive capacity of a community by an urban river, the neighbourhood becomes the setting. The next subsection explains the definition of adaptive capacity in relation to the urban river neighbourhood. 
Overview of a Community's Adaptive Capacity in an Urban River Neighbourhood

Adaptive capacity is primarily a social phenomenon in social-ecological systems and is one of the fundamentals for resilience (Choudhury \& Haque, 2016; Folke et al., 2010). The Intergovernmental Panel on Climate Change (IPCC) has defined adaptive capacity as 'the ability of systems, institutions, humans and other organisms to adjust to potential damage, to take advantage of opportunities or to respond to consequences'. In other words, it reflects the ability of systems to adjust to changes, moderate impact, and cope with potential damage or disturbance (Cutter et al., 2008; Wilson, 2012). Community resilience focuses on the state of communities after or whilst adapting to changes, whereas adaptive capacity refers to the communities' way of handling change. In this study, the adaptive capacity of an urban river neighbourhood community is evaluated based on the community's experience during floods and community events.

Adaptive capacity is sometimes expressed as a community's capacity to respond to surrounding changes (Robinson $\&$ Carson, 2015). As a community is unable to control all situations (Magis, 2010), the capacity is related to the diversity of responses that are based on available options, which reflects the community's flexibility in handling unexpected changes (Fazey et al., 2018; Holling \& Meffe, 1996). The adaptive capacity mainly depends on the communities' experiences of past and present events (Keen et al., 2005; Osborne et al., 2007; Wilson, 2012). The embedded experiences later became the communities' social memory, a factor responsible for shaping their next action after disturbance.

Social memory is related to memorised past events (von Bertalanffy, 1968). Schama (1995) noted that social memory is influenced by the impact of past events, and by understanding a community's actions, a better understanding of its neighbourhood's landscape can be achieved. The community's experiences in an urban river neighbourhood matter because they accumulate and become part of the community's social memory. Subsequently, they form a pathway that influences the community's adaptive capacity. The pathway is intricately related to social memory; it acts as a guide for the community and becomes the key to the community's resiliency (Wilson, 2014). The community is driven by social memory because the pathway is demonstrated by the influence of collective memories (Stark, 1991). In this study, the community's experiences are considered in order to understand its social memory and consequently, adaptive capacity.

This study focuses on the floods and community events experienced by a community. In an urban river neighbourhood, the community is closest to the river is the most affected. Because they are the most exposed to the river and the events that happen around it, they become the unit of analysis that gives a better reflection of the neighbourhood's adaptive capacity. 


\section{Gap of Study}

As the community became this study's data source, its adaptive capacity and its neighbourhood had to be considered together. Adaptive capacity is mostly studied in relation to disaster risk reduction and rural, whilst urban river neighbourhood is mostly studied concerning river restoration and river ecology. Not much attention has been given to the social aspect of urban river neighbourhoods and adaptive capacity. Table 1 summarises the studies related to adaptive capacity and urban river neighbourhoods.

Human intervention has been affecting all aspects of urban rivers, including the rivers' form and functions, on a global scale (Wohl, 2014). As a result, the rivers face persistent environmental issues since 2003, mainly pollution, as indicated by many authors (e.g.: Chan, 2005, 2012; Chan et al., 2003; Elfithri et al., 2011; Parsons \& Thoms, 2018).
Despite the pollution, there are still communities, excluding squatters, that live next to rivers and are reluctant to move. Their existence further indicates the need for the community to be highlighted in this study, as the issues relate to anthropogenic. It also suggests that the community has the ability to adapt. Furthermore, communities are considered as the root of the success of urban river neighbourhoods because they are the residents of the area, and offered pertinent information for this study. Wilson (2012) has provided a total of 35 drivers that are composed of economic (12 drivers), social (16 drivers), and environmental (7 drivers) capitals. This study adopted the social capital drivers to explore adaptive capacity further, as the aforementioned author did not specifically mention the setting. This study attempts to identify the drivers that existed in an urban river neighbourhood in Kg. Pertanian, Kulai, Johor as well as explore the neighbourhood through its community.

Table 1

A summary of studies related to adaptive capacity and urban river neighbourhoods, and the need to bridge the gap

\begin{tabular}{|c|c|c|c|c|}
\hline Topic & \multicolumn{2}{|c|}{ Adaptive capacity } & \multicolumn{2}{|c|}{ Urban river neighbourhood } \\
\hline Field & $\begin{array}{l}\text { Disaster risk } \\
\text { reduction }\end{array}$ & Rural studies & River restoration & River ecology \\
\hline Authors & $\begin{array}{l}\text { Ling and Chiang } \\
\text { (2018), Patel and } \\
\text { Gleason (2018), } \\
\text { Rufat et al. (2015) }\end{array}$ & $\begin{array}{l}\text { Chaudhury et al. (2017), } \\
\text { Jiang et al. (2016), } \\
\text { Lisnyj and Dickson- } \\
\text { Anderson (2018) }\end{array}$ & $\begin{array}{l}\text { Åberg and Tapsell } \\
\text { (2013), Chen et al. } \\
\text { (2018), Junker and } \\
\text { Buchecker (2008), } \\
\text { Podolak (2012) }\end{array}$ & $\begin{array}{l}\text { Jim and Chen } \\
\text { (2003), Schmidt et } \\
\text { al. (2016), Solins } \\
\text { et al. (2018) }\end{array}$ \\
\hline \multirow[t]{2}{*}{ Description } & \multicolumn{2}{|c|}{$\begin{array}{l}\text { Adaptive capacity is at its infancy in urban } \\
\text { river neighbourhoods (Hunter, 2011; Wilson, } \\
\text { 2012) }\end{array}$} & \multicolumn{2}{|c|}{$\begin{array}{l}\text { There is a need to give attention to the social } \\
\text { aspects of urban river neighbourhoods } \\
\text { (Chaffin \& Scown, 2018; Kumar et al., } \\
\text { 2018) because its focus has been solely on }\end{array}$} \\
\hline & \multicolumn{4}{|c|}{$\begin{array}{l}\text { Adaptive capacity in an urban river neighbourhood is essential to ensure that the } \\
\text { community and the neighbourhood can sustain through disturbances }\end{array}$} \\
\hline
\end{tabular}




\section{METHODS}

This study was conducted in an urban river neighbourhood and depended on its community's responses during focus group discussions and interviews to explore the community's adaptive capacity. The selection of the study area and respondents is described in the next subsection. The subsequent subsection explains the methods of data collection, and the last subsection elaborates on the tools of analysis.

\section{Selection of a Study Area and Respondents}

The neighbourhood is located in $\mathrm{Kg}$. Pertanian, Kulai, Johor. Kg. Pertanian is a 126-acre kampong that is surrounded by domestic, industrial, and residential lands. It is populated by 1400 residents and 248 houses and is close to the Skudai River, which is one of the 11 main rivers in Johor. The community is under the careful supervision of the Department of Irrigation and Drainage (DID) as the distance between its office with the neighbourhood is only 1.4 $\mathrm{km}$ (an 18-minute walk). Figure 1 illustrates the location plan of the study area. The close supervision from DID leads to better river issues exposure to the community. Because of this, Kg. Pertanian was chosen as the study area. Site visits were carried out for the researcher to be familiar with the neighbourhood and to establish rapport with its community.

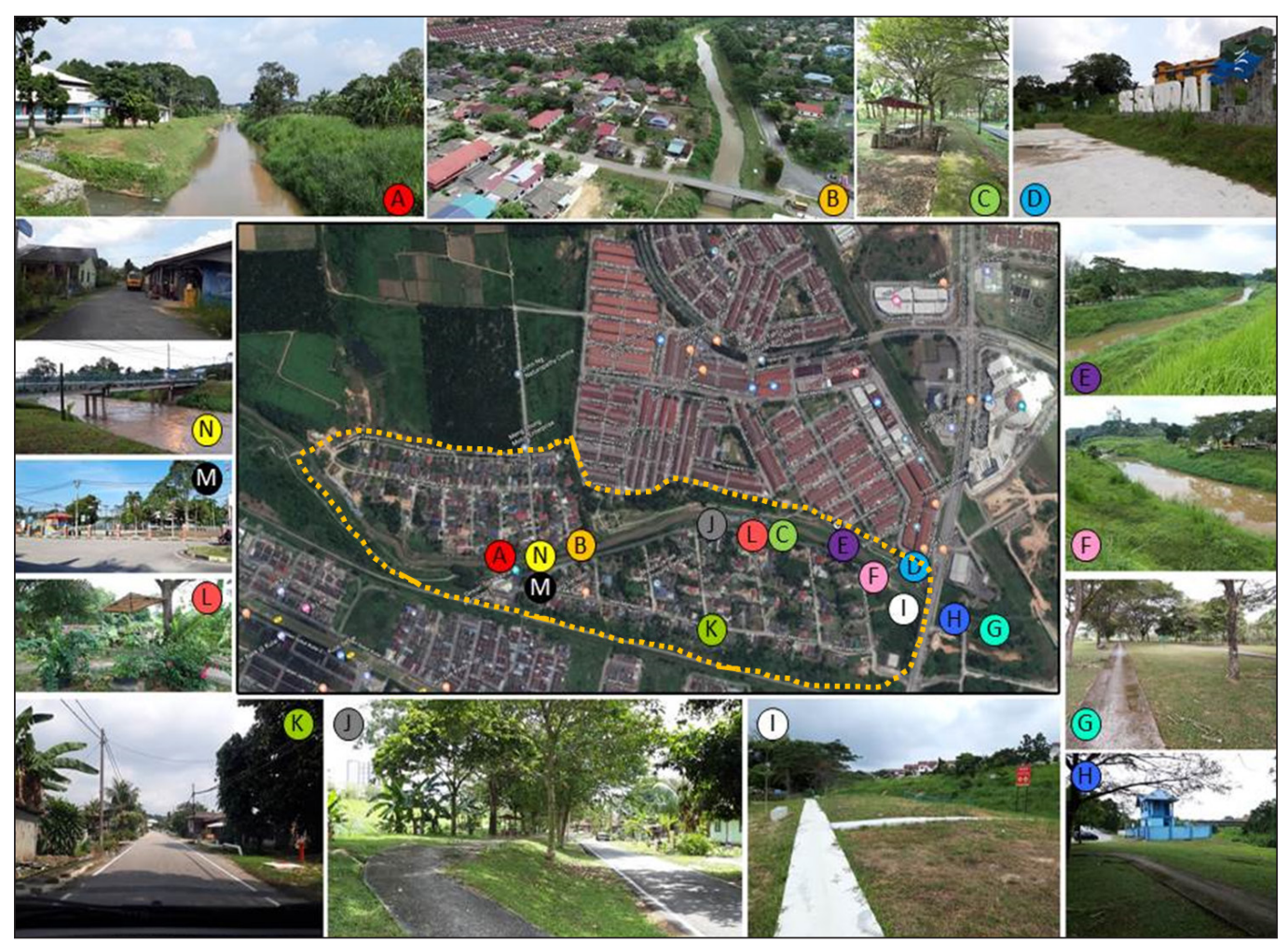

Figure 1. Location of of interest in Kg. Pertanian, Kulai, Johor 
A total of 27 residents that live near the river participated in the data collection. The respondents were selected based on their willingness to participate in focus group discussions. Their willingness signified their commitment to their neighbourhood (Robinson \& Carson, 2015) as they volunteered to elicit data regarding their adaptive capacity. Genuine and accurate responses during the discussions and interviews were guaranteed as they were dedicated. Because of constraints in terms of finance and transportation, non-probability sampling was used (Fink \& Gantz, 1996; Neuendorf, 2017) to elicit data from the residents. The sampling was also used because the discussions were conducted on a Wednesday, which was a working day. The day was decided by the representative from the community after it was agreed that most of them would be available to participate. It was unclear as to how many would be available; thus, the researcher did not expect any specific numbers of the respondents. This study adopted purposive sampling as it was purposely for the community of the urban river neighbourhood, of which residents were valid respondents due to their exposure to their surroundings.

\section{Focus Group Discussions and Personal Interviews}

Data were elicited from focus group discussions and subsequent personal interviews. Four focus group discussions were carried out during a community workshop held in the Dewan Pusat Aktiviti Warga Emas (PAWE) community hall. Before the discussions, two talks about river challenges and the role of communities were given by experts. Then, the discussions were carried out simultaneously due to time limitations. Each group consisted of five to seven respondents and a researcher's assistant as the moderator that will ask questions. Then, the respondents were briefed by the researcher about the focus group discussions' procedure. Figure 2 illustrates the flow of the workshop.

The sets of questions had four headings, namely (i) river issues, (ii) river management and maintenance, (iii) river environment preferences, and (iv) the neighbourliness in the neighbourhood. The questions focused on the community's awareness and perception of their experiences living close to a river. Each section consisted of four to ten questions, which were asked by the researcher's assistants. The assistants were

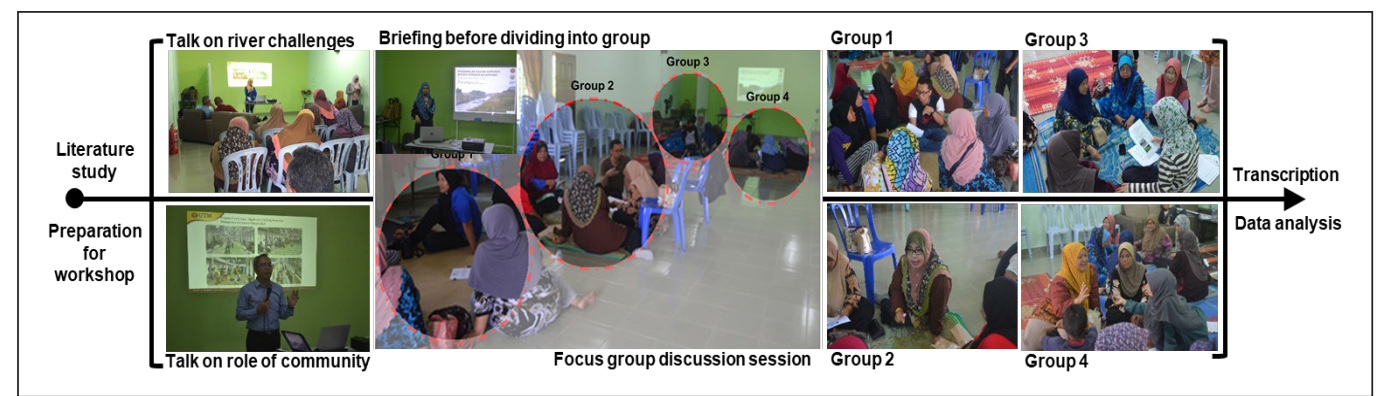

Figure 2. The flow of the community workshop, which included talks and focus group discussions 
also allowed to ask follow-up questions whenever necessary to elicit meaningful data and skip questions indirectly answered to other questions. In a qualitative study, the goal is to understand the processes and relationships within the unit of analysis (Neuman, 2014). Thus, the questions were improvised according to the situation to ensure that the respondents understood their meanings. The discussions took approximately 30 minutes and were recorded using the assistants' smartphones for the sake of convenience.

The much later personal interviews were carried out periodically to support the results and ensure the clarity of responses. The interviews were recorded using a smartphone and carried out at places most convenient to the respondents, such as somewhere near their homes or in the community hall. Four personal interviews were done with three respondents with time spent between five minutes up to an hour. These respondents were considered those who knew the neighbourhood the most because they were well known by the residents and played a part in the community's organisation. They knew the well-being of the residents the best. The interview questions were meant to clarify any unclear answers from the focus group discussion. Three interviews were recorded, while one was purposefully unrecorded to avoid inconvenience to other respondents. Despite that, notes from the respondent's feedback were still taken.

The responses to the discussions and interviews were recorded verbatim as they reflected real experiences in the urban river neighbourhood. Finally, the raw data were transcribed, translated from Bahasa Malaysia to English, and analysed using Nvivo12.

\section{Tools of Analysis}

The hierarchy chart in Nvivo12 was used to identify the drivers of the community's adaptive capacity in its urban river neighbourhood. The drivers are listed and discussed in the next section. The results were examined further using content analysis to explain the relationship that influenced their adaptive capacity.

As illustrated in Figure 3, the process of analysis started by listing the drivers outlined by Wilson (2012). Next, the transcript was read to identify statements that complemented the drivers adapted. It was irrelevant whether the statements indicated positive or negative impressions. The process continued by writing down manually all identified themes that complemented the drivers. Next, the transcript was reread carefully to identify the themes that reappeared in the discussions. There is meaning in reappearing themes, and thus, they must not be ignored (Krippendorff, 2004). Adaptive capacity became the foundation for the analysis, which would later provide a roadmap to generalisations (Neuendorf, 2017) regarding the community. The dominance of the drivers was based on assigned codes of the transcriptions (Tobi, 2016). Nvivo12 helped the researcher to be familiar with the data pattern and develop the relationship between drivers as well. In this paper, only the interrelation between the 


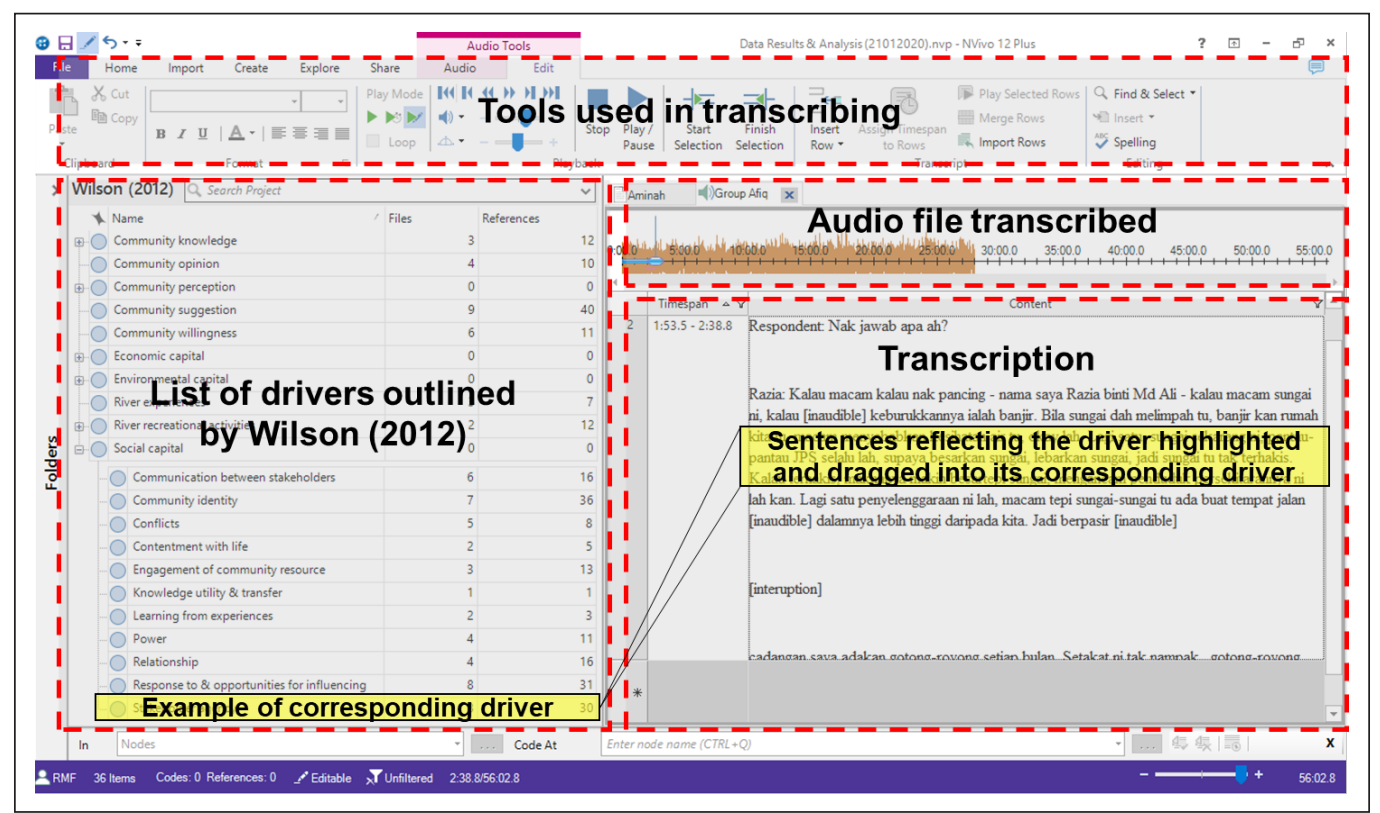

Figure 3. The interface of the audio transcription in Nvivo12

main drivers was focused on when trying to gain a deeper understanding of the adaptive capacity.

\section{RESULTS AND DISCUSSION}

This study adapted the social drivers from Wilson (2012) to examine the adaptive capacity of a community in an urban river neighbourhood. Out of 16 drivers, 11 were identified from the community's experiences, which means that these drivers influenced the way the community adapts to its living environment. Three drivers were found to be the most dominant, namely (i) community identity, (ii) community response, and (iii) stakeholder agency. How the three drivers became the main drivers that affected the community's adaptive capacity is discussed later. Figure 4 illustrates the dominance of the 11 drivers that were present in the neighbourhood.
It was found that the three drivers were connected by the community's interaction with its living environment and stakeholders in its neighbourhood. The following subsection explains the relationship between the community and the drivers. The subsection after that explains social memory's role in influencing the community's drivers, which reflected the community's adaptive capacity.

\section{The Relationship Between The Community And The Drivers}

The results shown are based on the community's experiences that involved interactions among the residents and stakeholders that took place in their urban river neighbourhood. Figure 5 shows the summarised of the three dominant drivers.

The most dominant driver is 'community identity', which describes the background of 


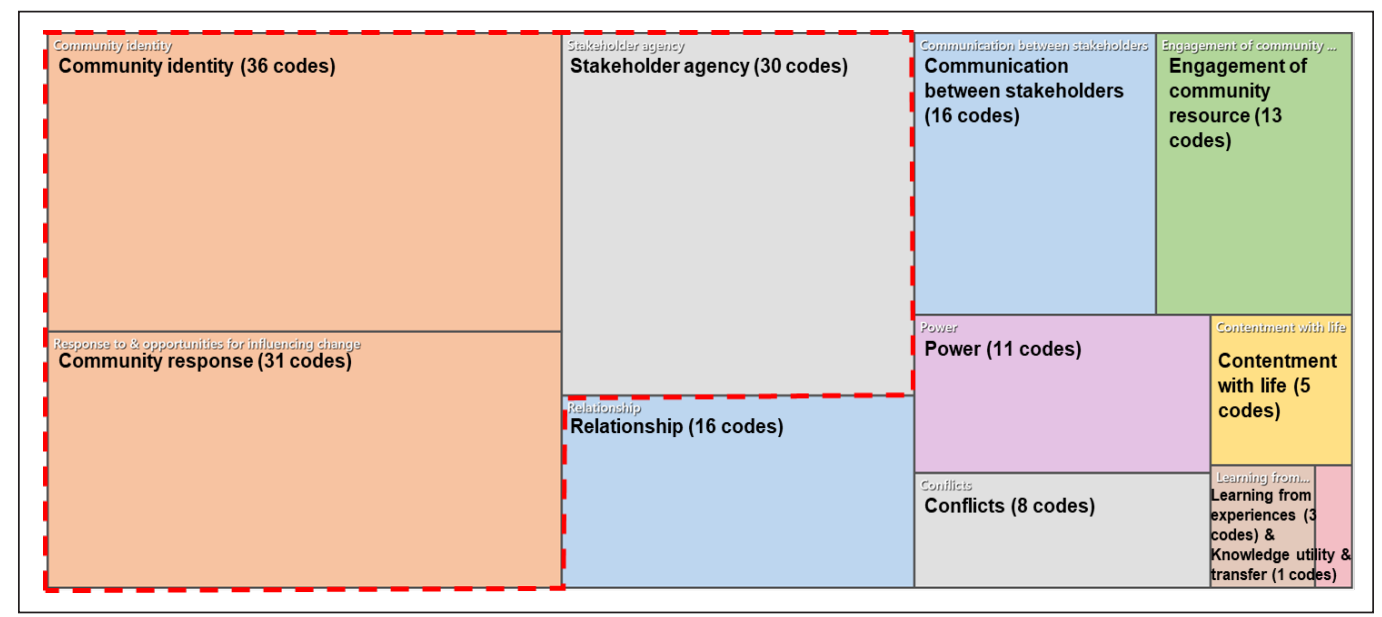

Figure 4. Community identity, community response, and stakeholder agency were the main drivers in the urban river neighbourhood

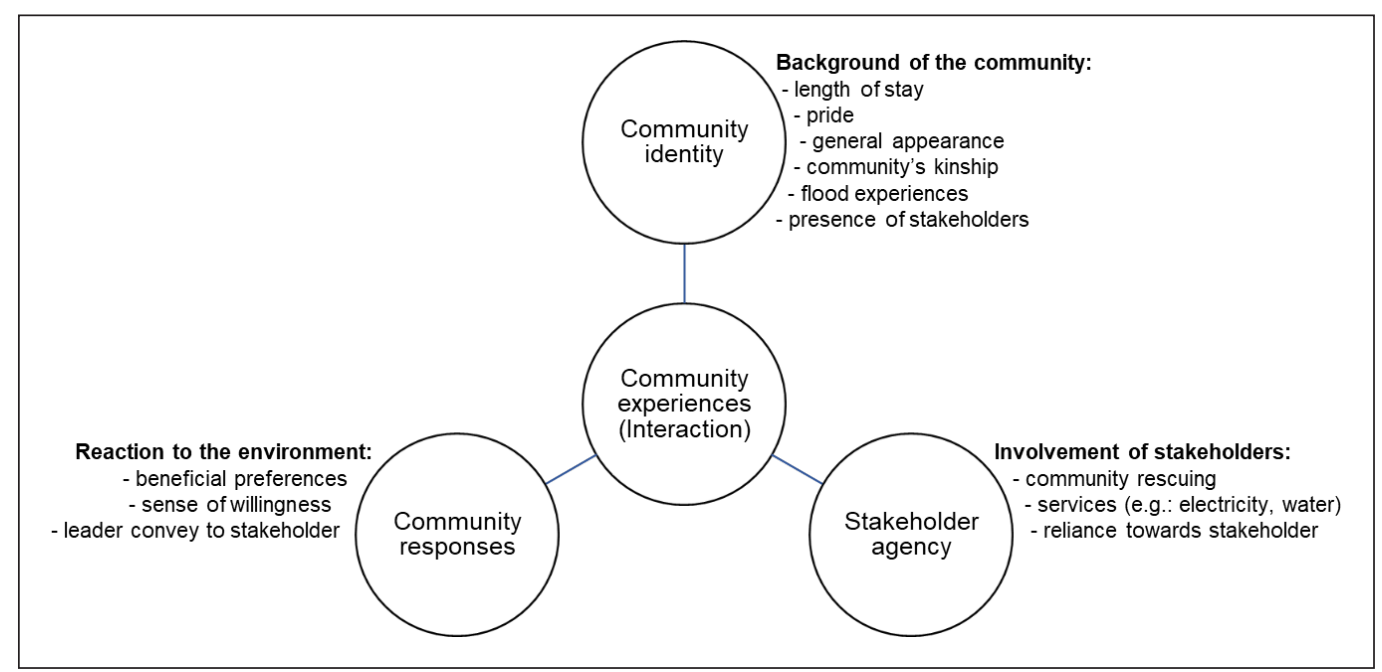

Figure 5. The three drivers that influenced the community's experiences in its urban river neighbourhood that involved interactions between the residents and the environment

the community and its neighbourhood. The driver is affected by the community's length of stay in the neighbourhood. It was the most dominant because the residents have stayed there for a long time, 49 years at most. The average length of stay was 21 years. The number of years showed that the residents were there long enough to see the changes that took place and experienced the frequent flooding in the neighbourhood before 2007. After that, their urban river was widened and deepened by stakeholders. According to one of the residents, the neighbourhood would be flooded every time it rained, which shows that flooding was frequent before the urban river was physically modified. The flood was 
worst in 2004, where they were forced to evacuate their neighbourhood and relocated to a neighbouring community hall as the water level reached rooftops, as illustrated in Figure 6. Multiple stakeholders, such as City Council, RELA (volunteers), and Kawasan Rukun Tetangga(KRT), assisted them during the evacuation. This engagement with multibackground stakeholders for assistance has become part of the community's identity and has helped them adapt to disturbance.

'Community identity' is also associated with a sense of pride for residents of the urban river neighbourhood. When the residents won the 'National Cleanest Kampung' competition three times in a row during the 1990s, they felt proud, which stemmed from the long length of stay mentioned in the previous paragraph. The pride trumped the devastation that they felt from the floods, and made them view their river more positively. The existence of fishes further supports the healthy status of their river. The existence was evident from the fishing activities that were part of their daily activities. In other words, the sense of pride from the community was associated with a well-managed ecosystem (Frischenbruder \& Pellegrino, 2006; Zinia \& McShane, 2018). In maintaining the ecosystem, the City Council also played a role. The council authorised pickup trucks to collect garbage around two to three times per week in the neighbourhood. The action of responsibility shows that with proper waste management, the risk of river pollution can be reduced, as well as nurture the community for better waste management. When it comes to urban river neighbourhoods, proper waste management is one of the factors that need to be addressed as it potentially reduces river pollution (Brotons \& Mallari, 2016) and leads to a community that perceives its neighbourhood as clean.

This finding encapsulates the residents' contentment with life because their wellbeing was taken care of by stakeholders. Additionally, they had a sense of kinship

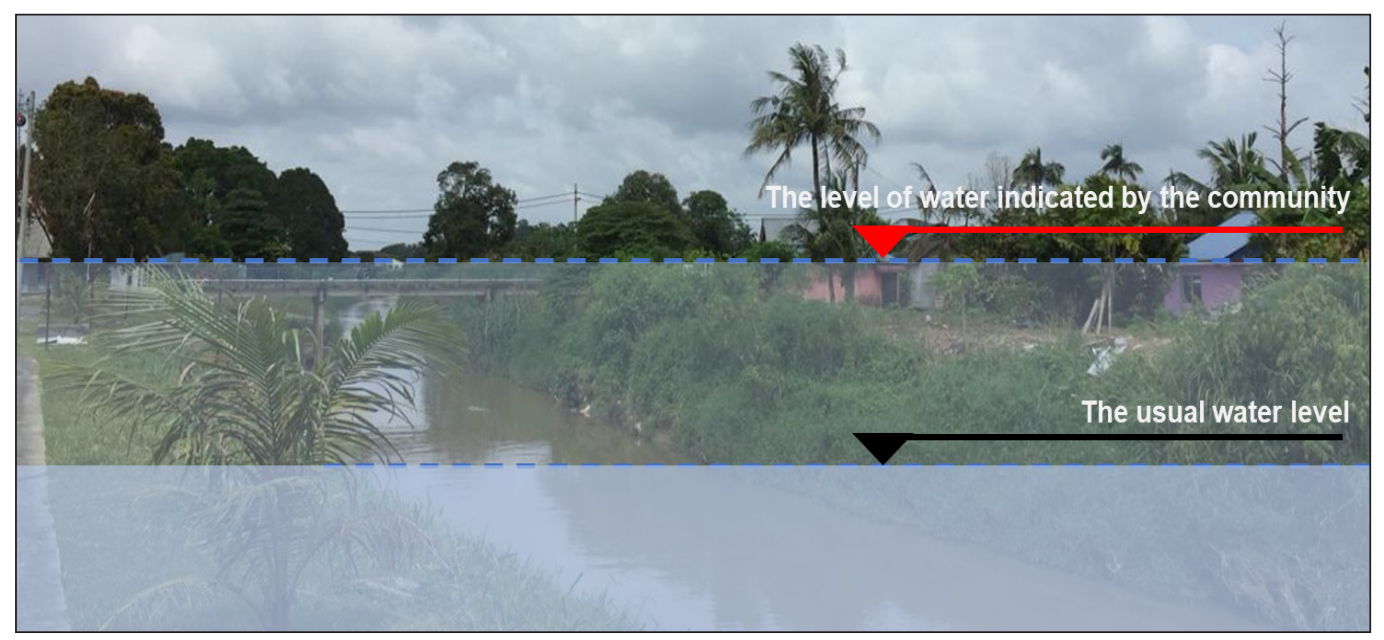

Figure 6. The approximate flood water level according to the community, compared with the usual water level 
with each other, which made bonding and connecting easier. This relationship further shows that the community shared a sense of trust and support among each other. For example, the community did not only just greet each other, but they shared stories of their everyday life. Their connection as neighbours made them appreciate the neighbourhood's environment. One of the residents said that even if she was provided with a better living environment elsewhere, she would prefer to stay because the values practised here made it comfortable for living.

Community events in the neighbourhood required the community's participation to be successful. Examples of such events include gotong-royong (the cleaning up of surrounding areas in preparation for events), kenduri (a Muslims-organised activity that includes prayer recitations and feasts but welcomes everyone), annual celebrations (e.g., Maulidur Rasul, Independence Day), and awareness campaigns. These events also provided opportunities for interaction, which aided the community in being socially connected (Granovetter, 1973). Being socially connected would lead a community to become resilient, and this has been supported by Nemeth and Olivier (2017). The community events represented the cultural background of the residents.

Their participation signifies familiarity between residents, which resulted in contentment when participating in community events. The participation also indicates that the people in the community had a sense of relatedness (Di Fabio \&
Saklofske, 2018) because of their kinship. Therefore, the idea of living in harmony, both environmentally and socially, included the changes after flood occurrences and community events. These enabled them to adapt to the disturbance in the urban river neighbourhood.

The second driver, 'community responses', denotes the community's way of reacting to changes that influenced its urban river neighbourhood. An example of changes is the reduction of flood risk through the widening and deepening of the neighbourhood's urban river. The significant modification was done by the Department of Irrigation and Drainage (DID) to ensure that flooding was mitigated. It succeeded, as the community no longer experience floods after 2007. The community's responses to changes after the 2007 flood can be categorised as follows.

(i) Preferred the same conditions: The community preferred the existing environment to be maintained in future developments.

(ii) Willing to try new things: The community was willing to try new things; the residents suggested improvements for their urban river neighbourhood.

(iii) Assimilation of both: The community preferred the existing environment with some improvements.

The responses show that the residents had different opinions on what would benefit them. The reason why some preferred their existing environment was because they 
appreciated what they already had, and this finding was supported by Asakawa et al. (2004). They did not experience flooding again, which made them feel content with the current environment.

Some residents were willing to experience new things, as they have seen firsthand the benefits of the past changes that were due to floods. They knew that the changes allowed them to overcome disturbances and continue living in their neighbourhood. The residents' acceptance of change shows that their experience has taught them the willingness to embrace change. One of the residents shared how the community's experience taught them not to buy expensive furniture for fear of more floods. Aside from willingness to change, the residents were also willing to share responsibility and knowledge. An example of responsibility-sharing can be seen through their preference for having local contractors participate in river management. They believed that it would be easier for them to report any river-related issues that might threaten their well-being. Through knowledge-sharing, they could provide information relevant to river management as they know details that were different from the authorities'. From these points, it can be said that knowledge through experience affected the community's adaptive capacity.

The final response is the assimilation of the first two, where some residents would tolerate some necessary changes to their existing environment, should the changes benefit their well-being. They provided suggestions for future improvements despite being somewhat content with their current lifestyle. They highlighted the need for landscaping, especially by the riverside. One of the residents suggested beautifying the river bank by planting more trees along the urban river. It is noteworthy that the opportunity for the community to be exposed to greenery is critical for the community's health and well-being (Hunter, 2011). These findings showed that they prefered to maintain the existing environment, but with some additional improvements. The suggestions given would definitely benefit them. It is affirmed that the community's responses towards their environment contributed to their ability to adapt to the urban river neighbourhood.

The third driver, 'stakeholder agency', refers to the involvement of local stakeholders with the community in the urban river neighbourhood. The stakeholders include the Department of Irrigation and Drainage (DID), RELA (volunteers), and Kawasan Rukun Tetangga (KRT). They played significant roles during the floods as the community needed rescuing back then. One of the residents described that during their hour of need, the community relied entirely on the stakeholders' support because that was the only help they had. Due to floods, the community and stakeholders became interconnected. After the urban river was widened and deepened, the approximately 2-meter everyday water level no longer exceeded. These aids from the stakeholders showed that their presence was essential for the community's survival. 
Moreover, the community received services such as water supply, electricity, and welfare fund from the stakeholders. Their well-being was guaranteed by the stakeholders, and this was beneficial for the residents. Consequently, the community was able to adapt when disturbances occurred. These findings showed that cooperation between the community and stakeholders' was needed to avert crises. Cooperation such as theirs is vital for a sustainable future (Dendler et al., 2012; Li et al., 2019) because they were the key players in the neighbourhood. Some studies regarding rural areas (Nørgaard \& Thuesen, 2020) also emphasised the relationship between stakeholders and the community.

Other than floods, community events that involved the stakeholders were also beneficial to the community's togetherness and awareness. An example of the event is Community in River (CoIR) in 2018. There were gotong-royong, competitions, and a talk that was given by the Department of Irrigation and Drainage (DID) aimed to increase the residents' awareness of their living environment. They expressed that they did not only participate in river cleaning, but also in fishing and drawing competitions. The community's participation proves that their engagement with their urban river contributed positively to their togetherness during the events. Their gathering also gave them the chance to interact with each other, thus promoting social cohesion (Fonseca et al., 2019; Granovetter, 1973) between the community and stakeholders.
Although awareness was not evident in the community, the fact that the urban river neighbourhood was their home indirectly instilled some consciousness about taking care of their surroundings. Their engagement with their river created a sense of willingness to experience change, as changes had benefitted them during past floods. In addition, they also experienced political change. In 2018, a conflict arose when the government appointed a new village head that was an outsider. The appointment affected them, as the village head act as their representative for communicating with stakeholders, which had always been local. Despite preferring the former village head, they accepted the new representative and were willing to get to know him. One resident even suggested a visit around the neighbourhood from the new village head in an effort to get to know him. This change shows that they were accepting in times of difficulties.

The village head's authority should always be complemented by the community's cooperation. Communication between the community and stakeholders about the community's needs is also vital as it has the potential to drive the community to be resilient. Thus, it is important for the community and stakeholders to be understanding to ensure that disturbance in the urban river neighbourhood can be overcome. One of the ways to establish such understanding is through the community responses, by which conflict during upcoming plans for the neighbourhood can be avoided. 


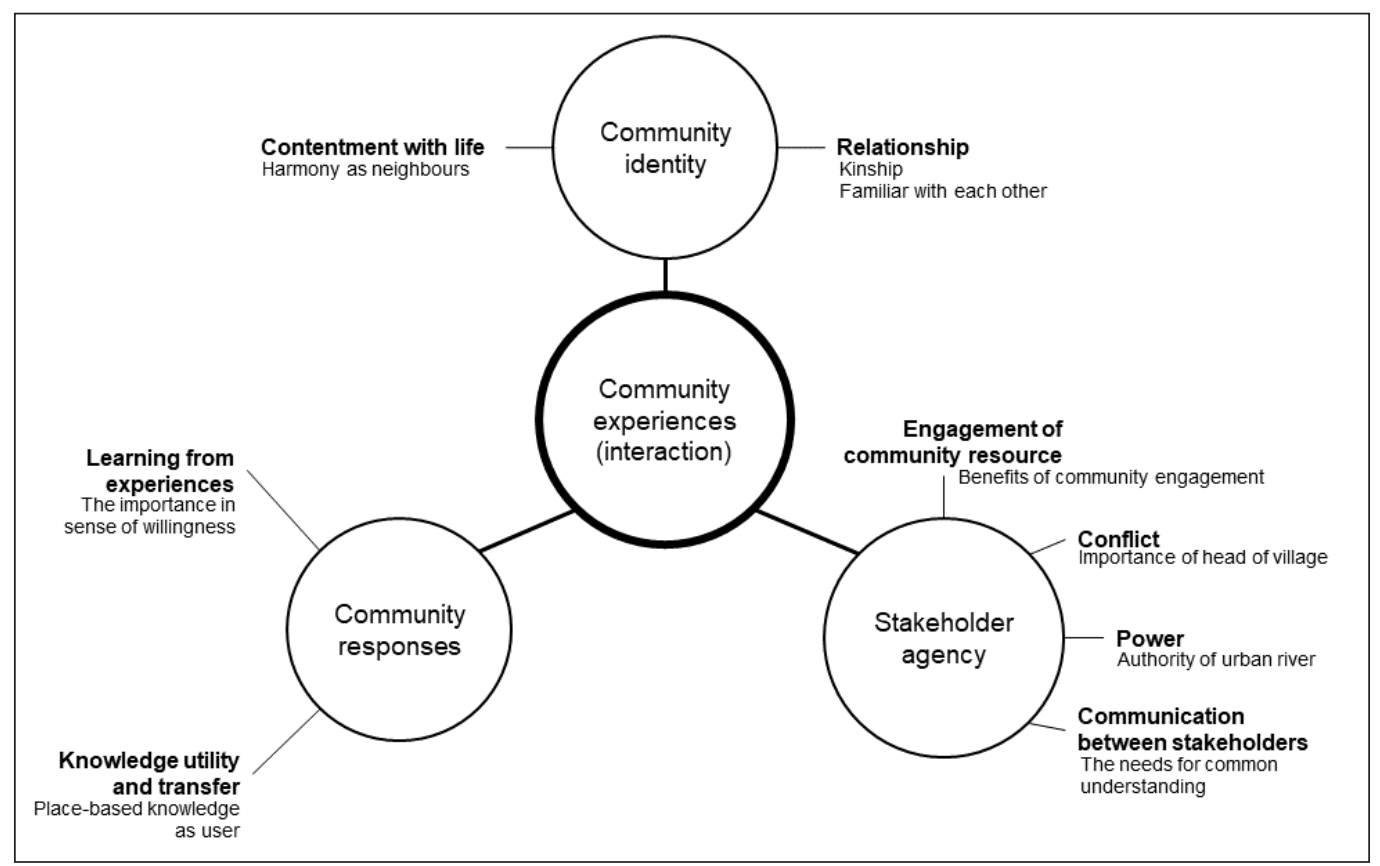

Figure 7. The three main drivers and eight supporting drivers that were identified to influence the adaptive capacity of the community in the urban river neighbourhood

Figure 7 summarises the identified drivers for the urban river neighbourhood community. The first is 'community identity', which is composed of contentment with life and neighbourly relationships in the urban river neighbourhood. It is essential for the community to be socially connected, especially in times of need. Secondly, 'community responses' include the process of learning from experience and using the knowledge to benefit their well-being. Thirdly, 'stakeholder agency' encompasses the community's engagement in ensuring the state of its urban river as a resource in its neighbourhood. However, the stakeholders still have authority over the urban river. For that reason, conflict is inevitable because it involves communication between the community and stakeholders. The main and supporting drivers identified must be considered in future planning for the urban river because they are the community's essence. It should be noted that the drivers are manipulated by past experiences or also known as social memory. The next subsection further elaborates the influence of social memory on the community's adaptive capacity in the urban river neighbourhood.

\section{Social Memory on the Adaptive Capacity of the Community in the Urban River Neighbourhood}

The frequent engagement between the people within the urban river neighbourhood has formed collective experiences or memories. As the community gains experiences, its neighbourhood grows, and the residents will develop a sense of familiarity with their 
river (Åberg \& Tapsell, 2013). The floods and community events also contributed to their familiarity. Their involvement with stakeholders was already within their social context, and it reflected the community's reliance. Their experiences would later accumulate into collective memories. As it depends on past and present events (Keen et al., 2005; Osborne et al., 2007; Wilson, 2012), the community's experiences with those events became one of the roots to the drivers that reflected the community's adaptive capacity. In other words, collective memories were responsible for shaping their adaptive capacity.

Other than past events, the formation of the community's social memory could also be attributed to the community's daily activities in $\mathrm{Kg}$. Pertanian. One of the residents, who had lived for 42 years in the neighbourhood, mentioned that she visited the urban river every day. The residents have been exposed to their surroundings every day, for 21 years. This exposure is common in natural and built-up areas (Samuelsson et al., 2018). That period allowed them to see changes and nurture their adaptive capacity through social memory.

Moreover, community events were still held in the neighbourhood, as they were part of the norm. The repeating events led to the accumulation of experience, which in turn became their social memory. The events also built social connectivity between the community, stakeholders, and their environment. For example, one of the residents who had stayed for 43 years mentioned that gotong-royong was carried out together with their neighbours. This helped the residents to be more socially connected, in addition to their kinship. Their closeness is supported by Nemeth and Olivier (2017)'s study, which emphasised the importance of being together. This closeness was already embedded within the community, which was evident from the community events. Hence, the social memory of the community involved togetherness and allowed the residents to be adaptive when living in the urban river neighbourhood.

\section{CONCLUSION}

In conclusion, the adaptive capacity of the community of $\mathrm{Kg}$. Pertanian along Skudai River in Kulai, Johor was based on the experiences gained from interactions with neighbours and stakeholders. Their adaptive capacity was also influenced by the flood experiences, in which stakeholders assisted them in times of need. Community events, including kenduri, gotong-royong, and daily activities such as walking and sightseeing, portrayed the importance of social connectivity within the urban river neighbourhood. The events and floods taught the community to be reliant on the stakeholders for adaptability, which later became part of their identity. This reliance would later benefit them and their neighbourhood, should disasters occur. It is also evident that their adaptive capacity was influenced by social bonding through interactions with the stakeholders. It can be said that the community's adaptive capacity within the neighbourhood was fueled by 
its experiences, which also influenced the three drivers: 'community's identity', 'community's responses', and 'stakeholder agencies'.

Based on these findings, it is believed that readers in the built environment field will be able to incorporate the social phenomena in the river neighbourhood into other parts of social science. The drivers identified in this study can also be studied as a topic of psychology or some other field because this study did not explore the community's behaviour. The findings could also help in the landscape design of places close to rivers to show how the environment is significant to people who use it regularly. The study limitations focused only on a particular neighbourhood: a river neighbourhood. It should be noted that the community's points of view are dynamic and change from time to time. Because of the dynamics, this study's findings may not apply to the following generations. Despite that, it is believed that this study can be beneficial to future generations facing an uncertain future. Adaptive capacity is a process that somehow guides communities to evolve based on social memory. Thereby, it presented the process of community change and the drivers that influenced the change.

This study extends the knowledge boundary of resilience, from which adaptive capacity originates. As mentioned in the gap of study, adaptive capacity is still in infancy (Hunter, 2011; Wilson, 2012). The focus that this study put on a river neighbourhood adds to the social aspect of resilience study.
This study offers an insight to stakeholders on the social phenomena present in the river neighbourhood community. The community's norm is essential and should be considered in future river development as the river is part of their home. Thus, stakeholders should consider using the bottom-up approach in the future. The combination of the bottom-up and topbottom approaches can ensure a more holistic approach. It is hoped that this study will benefit those who appreciate the river as one of life's sources through the exposure of adaptive capacity.

\section{ACKNOWLEDGEMENT}

This research has not been possible without the fund from Universiti Teknologi Malaysia: Knowledge Transfer Program - Networking Matching Grant (UTM KTP-NMG 2018) and the support from the members of the Greenovation Research group in conducting the data collection. I am grateful for the cooperation from the Department of Irrigation and Drainage (DID) for being part of the data collection and continuous guidance from my supervisors.

\section{REFERENCES}

Åberg, E. U., \& Tapsell, S. (2013). Revisiting the River Skerne: The long-term social benefits of river rehabilitation. Landscape and Urban Planning, 113, 94-103. https://doi.org/10.1016/j. landurbplan.2013.01.009

Asakawa, S., Yoshida, K., \& Yabe, K. (2004). Perceptions of urban stream corridors within the greenway system of Sapporo, Japan. Landscape and Urban Planning, 68(2), 167-182. https://doi. org/10.1016/S0169-2046(03)00158-0 
Baschak, L., \& Brown, R. (1994). River systems and landscape networks. Landscape Planning and Ecological Networks, 6, 179.

Brotons, J. C., \& Mallari, J. (2016, November 4). How to revive an ailing river. Development Asia. https://development.asia/case-study/howrevive-ailing-river

Chaffin, B. C., \& Scown, M. (2018). Socialecological resilience and geomorphic systems. Geomorphology, 305, 221-230. https://doi. org/10.1016/j.geomorph.2017.09.038

Chan, N. W. (2005). Sustainable management of rivers in Malaysia: Involving all stakeholders. International Journal of River Basin Management, 3(3), 147-162. https://doi.org/10 $.1080 / 15715124.2005 .9635254$

Chan, N. W. (2009). Issues and challenges in water governance in Malaysia. Iranian Journal of Environmental Health Science \& Engineering, 6(3), 143-152.

Chan, N. W. (2012). Managing urban rivers and water quality in Malaysia for sustainable water resources. International Journal of Water Resources Development, 28(2), 343-354. https:// doi.org/10.1080/07900627.2012.668643

Chan, N. W., Abdullah, A. L., Ibrahim, A. L., \& Ghazali, S. (2003). River pollution and restoration towards sustainable water resources management in Malaysia [Paper presentation]. Society, Space \& Environment in a Globalised World: Challenges and Prospects, Penang, Malaysia.

Chaudhury, A. S., Thornton, T. F., Helfgott, A., Ventresca, M. J., \& Sova, C. (2017). Ties that bind: Local networks, communities and adaptive capacity in rural Ghana. Journal of Rural Studies, 53, 214-228. https://doi.org/10.1016/j. jrurstud.2017.05.010

Chen, W. Y., Hua, J., Liekens, I., \& Broekx, S. (2018). Preference heterogeneity and scale heterogeneity in urban river restoration: A comparative study between Brussels and Guangzhou using discrete choice experiments. Landscape and Urban Planning, 173, 9-22. https://doi.org/10.1016/j. landurbplan.2018.01.010

Chiang, Y.-C. (2018). Exploring community risk perceptions of climate change - A case study of a flood-prone urban area of Taiwan. Cities, 74, 4251. https://doi.org/10.1016/j.cities.2017.11.001

Choudhury, M.-U.-I., \& Haque, C. E. (2016). "We are more scared of the power elites than the floods": Adaptive capacity and resilience of wetland community to flash flood disasters in Bangladesh. International Journal of Disaster Risk Reduction, 19, 145-158. https://doi. org/10.1016/j.ijdrr.2016.08.004

Cutter, S. L., Barnes, L., Berry, M., Burton, C., Evans, E., Tate, E., \& Webb, J. (2008). A place-based model for understanding community resilience to natural disasters. Global Environmental Change, 18(4), 598-606. https://doi.org/10.1016/j. gloenvcha.2008.07.013

Darby, S., \& Sear, D. (2008). River restoration: Managing the uncertainty in restoring physical habitat. John Wiley \& Sons, Ltd.

Dendler, L., Sharmina, M., Calverley, D., \& Traut, M. (2012). Sustainable futures: Multi-disciplinary perspectives on multi-level transitions. Environmental Development, 2, 2-5. https:/doi. org/10.1016/j.envdev.2012.03.002

Di Fabio, A., \& Saklofske, D. H. (2018). The contributions of personality and emotional intelligence to resiliency. Personality and Individual Differences, 123, 140-144. https:// doi.org/10.1016/j.paid.2017.11.012

Elfithri, R., Toriman, M., Mokhtar, M., \& Juahir, H. (2011). Perspectives and initiatives on integrated river basin management in Malaysia: A review. The Social Sciences, 6(2), 169-176. https://doi. org/10.3923/sscience.2011.169.176 
Eze, P. N., \& Knight, J. (2018). A geomorphological characterisation of river systems in South Africa: A case study of the Sabie River. Physics and Chemistry of the Earth, Parts A/B/C, 105, 196205. https://doi.org/10.1016/j.pce.2018.01.001

Fazey, I., Carmen, E., Chapin, F. S., Ross, H., Rao-Williams, J., Lyon, C., Connon, I. L. X., Searle, B. A., \& Knox, K. (2018). Community resilience for a $1.5^{\circ} \mathrm{C}$ world. Current Opinion in Environmental Sustainability, 31, 30-40. https:// doi.org/10.1016/j.cosust.2017.12.006

Fink, E. J., \& Gantz, W. (1996). A content analysis of three mass communication research traditions: Social science, interpretive studies, and critical analysis. Journalism \& Mass Communication Quarterly, 73(1), 114-134. https://doi. org/10.1177/107769909607300111

Folke, C., Carpenter, S. R., Walker, B., Scheffer, M., Chapin, T., \& Rockström, J. (2010). Resilience thinking: Integrating resilience, adaptability and transformability. Ecology and Society, 15(4), 20.

Fonseca, X., Lukosch, S., \& Brazier, F. (2019). Social cohesion revisited: A new definition and how to characterise it. Innovation: The European Journal of Social Science Research, 32(2), 231-253. https://doi.org/10.1080/13511610.20 18.1497480

Frischenbruder, M., \& Pellegrino, P. (2006). Using greenways to reclaim nature in Brazilian cities. Landscape and Urban Planning, 76(1), 67-78. https://doi.org/10.1016/j. landurbplan.2004.09.043

Gleye, P. H. (2015). City planning versus urban planning: Resolving a profession's bifurcated heritage. Journal of Planning Literature, 30(1), 3-17. https://doi.org/10.1177/0885412214554088

Granovetter, M. S. (1973). The strength of weak ties. American Journal of Sociology, 78(6), 1360-1380.
Gregory, K. J. (2006). The human role in changing river channels. Geomorphology, 79(3), 172-191. https://doi.org/10.1016/j.geomorph.2006.06.018

Harper, C. L. (2004). Environment and society: Human perspectives on environmental issues. Pearson/Prentice Hall.

Holling, C. S., \& Meffe, G. K. (1996). Command and control and the pathology of natural resource management. Conservation Biology, 10(2), 328-337.

Hunter, M. R. (2011). Impact of ecological disturbance on awareness of urban nature and sense of environmental stewardship in residential neighborhoods. Landscape and Urban Planning, 101(2), 131-138. https://doi.org/10.1016/j. landurbplan.2011.02.005

Jiang, W., Deng, Y., Tang, Z., Cao, R., Chen, Z., \& Jia, K. (2016). Adaptive capacity of mountainous rural communities under restructuring to geological disasters: The case of Yunnan Province. Journal of Rural Studies, 47(Part B), 622-629. https://doi.org/10.1016/j. jrurstud.2016.05.002

Jim, C. Y., \& Chen, S. S. (2003). Comprehensive greenspace planning based on landscape ecology principles in compact Nanjing city, China. Landscape and Urban Planning, 65(3), 95-116. https://doi.org/10.1016/S0169-2046(02)00244-X

Junker, B., \& Buchecker, M. (2008). Aesthetic preferences versus ecological objectives in river restorations. Landscape and Urban Planning, 85(3), 141-154. https://doi.org/10.1016/j. landurbplan.2007.11.002

Keen, M., Brown, V. A., \& Dyball, R. (2005). Social learning in environmental management: Towards a sustainable future. Routledge.

Krippendorff, K. (2004). Content analysis: An introduction to its methodology. Sage. 
Kumar, P., Masago, Y., Mishra, B. K., \& Fukushi, K. (2018). Evaluating future stress due to combined effect of climate change and rapid urbanisation for Pasig-Marikina River, Manila. Groundwater for Sustainable Development, 6, 227-234. https:// doi.org/10.1016/j.gsd.2018.01.004

Li, Y., Beeton, R. J. S., Sigler, T., \& Halog, A. (2019). Enhancing the adaptive capacity for urban sustainability: A bottom-up approach to understanding the urban social system in China. Journal of Environmental Management, 235, 51-61. https://doi.org/10.1016/j. jenvman.2019.01.044

Ling, T.-Y., \& Chiang, Y.-C. (2018). Strengthening the resilience of urban retailers towards flood risks - A case study in the riverbank region of Kaohsiung City. International Journal of Disaster Risk Reduction, 27, 541-555. https:// doi.org/10.1016/j.ijdrr.2017.11.020

Lisnyj, K. T., \& Dickson-Anderson, S. E. (2018). Community resilience in Walkerton, Canada: Sixteen years post-outbreak. International Journal of Disaster Risk Reduction, 31, 196-202. https://doi.org/10.1016/j.ijdrr.2018.05.001

Magis, K. (2010). Community resilience: An indicator of social sustainability. Society \& Natural Resources, 23(5), 401-416. https://doi. org/10.1080/08941920903305674

Md. Yassin, A., Eves, C., \& McDonagh, J. (2010, January 24-27). An evolution of waterfront development in Malaysia [Paper presentation]. 16th annual conference of the Pacific Rim Real Estate Society, Wellington, New Zealand.

Nemeth, D. G., \& Olivier, T. W. (2017). Resilience: Defined and explored. In D. G. Nemeth \& T. W. Olivier (Eds.), Innovative approaches to individual and community resilience (pp. 1-23). Academic Press.

Neuendorf, K. A. (2017). The content analysis guidebook (2nd ed.). SAGE Publications.
Neuman, W. L. (2014). Social research methods: Quantitative and qualitative approaches (7th ed.). Pearson Education Limited.

Nørgaard, H., \& Thuesen, A. A. (2020). Rural community development through competitions, prizes, and campaigns: The villagers' perspective. Journal of Rural Studies, In Press. https://doi. org/10.1016/j.jrurstud.2020.03.006

Osborne, M., Sankey, K., \& Wilson, B. (2007). Social capital, lifelong learning and the management of place: An international perspective. Taylor $\&$ Francis.

Palmer, M., Lettenmaier, D., Poff, N., Postel, S., Richter, B., \& Warner, R. (2009). Climate change and river ecosystems: Protection and adaptation options. Environmental Management, 44, 1053-1068. https://doi.org/10.1007/s00267009-9329-1

Parsons, M., \& Thoms, M. C. (2018). From academic to applied: Operationalising resilience in river systems. Geomorphology, 305, 242-251. https:// doi.org/10.1016/j.geomorph.2017.08.040

Patel, R. B., \& Gleason, K. M. (2018). The association between social cohesion and community resilience in two urban slums of Port au Prince, Haiti. International Journal of Disaster Risk Reduction, 27, 161-167. https://doi.org/10.1016/j. ijdrr.2017.10.003

Podolak, K. N. (2012). Multifunctional riverscapes: Stream restoration, Capability Brown's water features, and artificial whitewater [Doctoral dissertation, University of California, Berkeley]. https://escholarship.org/uc/item/0c18207s

Rahman, H. S. N. A., \& Yatim, O. M. (1990). Antiquities of Bujang Valley. Museum Association of Malaysia.

Robinson, G., \& Carson, D. (2015). Resilient communities: Transitions, pathways and resourcefulness: Resilient communities. The Geographical Journal, 182(2), 114-122. https:// doi.org/10.1111/geoj.12144 
Rufat, S., Tate, E., Burton, C. G., \& Maroof, A. S. (2015). Social vulnerability to floods: Review of case studies and implications for measurement. International Journal of Disaster Risk Reduction, 14(4), 470-486. https://doi.org/10.1016/j. ijdrr.2015.09.013

Sakai, N., Mohamad, Z. F., Nasaruddin, A., Abd Kadir, S. N., Salleh, M. S. A. M., \& Sulaiman, A. H. (2018). Eco-Heart Index as a tool for community-based water quality monitoring and assessment. Ecological Indicators, 91, 38-46. https://doi.org/10.1016/j.ecolind.2018.03.079

Samuelsson, K., Giusti, M., Peterson, G. D., Legeby, A., Brandt, S. A., \& Barthel, S. (2018). Impact of environment on people's everyday experiences in Stockholm. Landscape and Urban Planning, 171, 7-17. https://doi.org/10.1016/j. landurbplan.2017.11.009

Schama, S. (1995). Landscape and memory. A.A. Knopf.

Schmidt, K., Sachse, R., \& Walz, A. (2016). Current role of social benefits in ecosystem service assessments. Landscape and Urban Planning, 149, 49-64. https://doi.org/10.1016/j. landurbplan.2016.01.005

Solins, J. P., Thorne, J. H., \& Cadenasso, M. L. (2018). Riparian canopy expansion in an urban landscape: Multiple drivers of vegetation change along headwater streams near Sacramento, California. Landscape and Urban Planning, 172, 37-46. https://doi.org/10.1016/j. landurbplan.2017.12.005

Stark, D. (1991). Path dependence and privatisation strategies in East Central Europe. East European
Politics and Societies, 6(1), 17-54. https://doi. org/10.1177/0888325492006001003

Tobi, S. (2016). Qualitative research, interview analysis \& Nvivoll exploration. Abdul Rahim Abdul Shukor (ARAS).

Verbrugge, L., \& van den Born, R. (2018). The role of place attachment in public perceptions of a relandscaping intervention in the river Waal (The Netherlands). Landscape and Urban Planning, 177, 241-250. https://doi.org/10.1016/j. landurbplan.2018.05.011

von Bertalanffy, L. (1968). General system theory: Foundations, development, applications. G. Braziller.

Wang, Z. (2018). Evolving landscape-urbanisation relationships in contemporary China. Landscape and Urban Planning, 171, 30-41. https://doi. org/10.1016/j.landurbplan.2017.11.010

Wilson, G. A. (2012). Community resilience and environmental transitions. Routledge.

Wilson, G. A. (2014). Community resilience: Path dependency, lock-in effects and transitional ruptures. Journal of Environmental Planning and Management, 57(1), 1-26. https://doi.org/1 $0.1080 / 09640568.2012 .741519$

Wohl, E. (2014). Rivers in the landscape: Science and management. Wiley.

Zinia, N. J., \& McShane, P. (2018). Ecosystem services management: An evaluation of green adaptations for urban development in Dhaka, Bangladesh. Landscape and Urban Planning, 173, 23-32. https://doi.org/10.1016/j. landurbplan.2018.01.008 